\title{
Influence of Kinako Manufacturing Process on the Isoflavone Profile
}

\author{
Influência do Processo de Fabricação de Kinako no Perfil de Isoflavonas
}

\author{
Letícia Cardoso da Silva ${ }^{a}$; Silvia Benedettia ; Josemeyre Bonifácio da Silva Marques*b
}

aUniversidade Estadual de Londrina, Programa de Pós-Graduação em Ciência de Alimentos. PR, Brazil.

bUnopar, Programa de Pós-Graduação Stricto Sensu em Ciência e Tecnologia de Leite e Derivados. PR, Brazil.

*E-mail: josemeyre.marques@kroton.com.br

\begin{abstract}
The soy aglycone isoflavone forms are major bioactive compounds associated with the promotion health. During thermal processing for production of soyfoods occur change the level and profile of isoflavones, but thermal stability and interconversion of these compounds have not been fully clarified. The aim of this study was to investigate the different times and temperatures effects during the preparation of whole roasted soybean flour (kinako) on the interconversion of glucoside isoflavones forms into aglycones. The grains of the soybean cultivar BRS 267 were subjected to different times $(10,15$ and $20 \mathrm{~min})$ and temperatures $\left(180,210\right.$ and $\left.240{ }^{\circ} \mathrm{C}\right)$ following a Central Composite Design (DCC) $2^{2}$. After, the grains were ground and defatted to extraction and quantification of the different forms of isoflavones by ultra high performance liquid chromatography (UHPLC). The effect of time and temperature during obtained of the kinako on the $\beta$-glucosides and malonylglucosides content was significant negative and linear and on the aglycones levels was significant negative and quadratic. Whole roasted soybean flour or kinako prepare at $210^{\circ} \mathrm{C}$ for $15 \mathrm{~min}$ has a the higher genistein content.
\end{abstract}

Keywords: Roasted Soybean Flour. Thermal Treatment. Genistein.

\section{Resumo}

As formas agliconas das isoflavonas de soja são os principais compostos bioativos associados à promoção da saúde. Durante o processamento térmico para produção de alimentos de soja ocorrem alterações no nivel e no perfil das isoflavonas, porém, a estabilidade térmica e a interconversão desses compostos não foram totalmente esclarecidas. O objetivo deste estudo foi investigar os efeitos de diferentes tempos e temperaturas durante o preparo da farinha integral de soja torrada (kinako) na interconversão das formas de glicosídicas das isoflavonas em agliconas. Os grãos da cultivar de soja BRS 267 foram submetidos a diferentes tempos (10, 15 e 20 min) e temperaturas (180, 210 e $240{ }^{\circ} \mathrm{C}$ ) seguindo um Delineamento Composto Central (DCC) $2^{2}$. Em seguida, os grãos foram moídos e desengordurados para à extração e quantificação das diferentes formas de isoflavonas por Cromatografia Líquida de Ultra Alta Eficiência (CLUAE). O efeito do tempo e da temperatura durante a obtenção do kinako sobre o teor de $\beta$-glicosídeos e malonilglicosídeos foi negativo e linear e sobre os níveis de agliconas foi significativamente negativo e quadrático. A farinha de soja integral torrada ou kinako preparada a $210{ }^{\circ} \mathrm{C}$ por $15 \mathrm{~min}$ tem um maior teor de genisteína.

Palavras chaves: Farinha de Soja Torrada. Tratamento Térmico. Genisteína.

\section{Introduction}

Soy isoflavones are bioactive compounds that showed beneficial effects to human health in the prevention of chronic degenerative diseases such as breast cancer and prostate cancer (PABICH, MATERSKA, 2019), osteoporosis, menopause symptoms (LEVIS et al. 2010), cardiovascular disease (RIMBACH et al. 2008) estrogenic and antioxidant activity (LIU et al. 2010), antitumor action (PABICH, MATERSKA, 2019) neuroprotectant (DING et al., 2019).

Soybean has four different isoflavones forms: $\beta$-glucosides (daidzin, genistin and glycitin), 6"-O-malonylglucosides (malonyldaidzin, malonylgenistin, malonylglycitin), 6"-O-acetilglucosides (acetildaidzin, acetilgenistin, acetilglycitin) and the aglycones (daidzein, genistein and glycitein) (LIU, 1997). The glucosides forms are the most isoflavones forms in the soybean grains and the bioavailability of isoflavones can be influenced by their chemical form in foods and the susceptibility to degradation during heating (BIRT et al., 2001). The aglycone forms show higher activity and are readily bioavalibity to organism human (HSIAO; HO; PAN, 2020).

Many studies have been shown the changes that can occur in the profile and level of soybean isoflavones due to thermal degradation and interconversion of glucosides forms into aglycones by $\beta$-glucosidase enzyme activity (LIMA; IDA, 2014; YUE et al., 2010; CHEN et al., 2019). The $\beta$-glucosidase enzyme is naturally present in soybean and is responsible to convert isoflavones into aglycones (FANG et al., 2016)IC50 values (the amount required for inhibiting $50 \%$ enzyme activity. Lima and Ida (2014) conclude that the soybean hydrothermal treatment favored $\beta$-glucosidase activity for the conversion of $\beta$-glucoside isoflavones to aglycones contributing to the preparation of soyfoods rich in aglycones. Yue et al. (2010) showed the higher thermal stability of aglycones forms when compared with glucosides 
forms showing the conversion of $\beta$-glucosides into aglycones at temperature greater than $150^{\circ} \mathrm{C}$. Lima et al. (2014) showed that processes of dry heat during bread making did not affect the total isoflavone content, but changed glucosides/ acetylglucosides to aglycones and conclude that the results provide critical information for the production of functional soy that contain varying amounts of soy isoflavones. Xu et al. (2002) verified that daidzin, glycitin, and genistin were loss of their original concentration after $3 \mathrm{~min}$ at $185^{\circ} \mathrm{C}$ and at 215 ${ }^{\circ} \mathrm{C}$, decreases of daidzin, glycitin, and genistin. The authors conclude that the order of the thermal stabilities, from lowest to highest, was glycitin, genistin, and daidzin.

Whole roasted soybean flour or popularly known as kinako is obtained by heating the grains in a conventional oven at appropriated temperature and time to release of the hulls. After, the roasted soybean grains are milled. The kinako can be used as ingredient in various non-meat and meat products to improve their physicochemical and functional properties (HOSODA et al. 2011, GENOVESE et al., 2007).

Appropriated time and temperature during thermal processing to produce soyfoods and that guarantee the most availability of isoflavones and consequentially of aglycones forms has not been discussed in literature. The aim of this study was to investigate the different times and temperatures effects during the preparation of whole roasted soybean flour (kinako) on the interconversion of glucoside isoflavones forms into aglycones using Central Composite Design (DCC) $2^{2}$.

\section{Development}

\subsection{Methodology}

\subsubsection{Materials}

Soybean of cultivar BRS 267 is food type and were supplied by Brazilian Agricultural Research Corporation (EMBRAPA/ Soja, Londrina, Parana, Brasil). For the determination of the isoflavones, the standards 6"-O-acetylglycosides and 6"-O-malonylglycosides (Wako Pure Chemical Industries, Ltd., Osaka, Japan) and $\beta$-glycosides and aglycones (SigmaAldrich Co., St. Louis, MO, USA) were used. All other reagents used were of analytical grade or chromatographic grade.

\subsection{Effect of heat treatment during toasting of soybean on the profile of isoflavones}

To evaluate the effect of heat treatment during toasting of soybeans on the profile of isoflavones, a Central Composite Design (CCD) $2^{2}$ was applied with three replicates at the central point, 11 assays that were performed randomly. For each assay, the soybean grains were toasted at different times $\left(X_{1}=10,15\right.$ and $\left.20 \mathrm{~min}\right)$ and temperatures $\left(X_{2}=180,210\right.$ and $240^{\circ} \mathrm{C}$ ) according to the $\mathrm{CCD}$ (Table 1). The toasted soybean grains in different assays were ground in a knife grinder (100 mesh) (TE 631, Tecnal, Brazil) and obtained the toasted soybean flour or kinako. The response functions evaluated were $\beta$-GLU ( $\beta$-glucosides), MGLU (malonylglucosides), and AGEN (genistein) contents.

Table 1 - The central composite design $2^{2}$ (CCD) with coded and real levels for independent variables and response functions

\begin{tabular}{|c|c|c|c|c|c|}
\hline Assays & $\begin{array}{c}\text { Indenpendent } \\
\text { variables and } \\
\text { coded levels } \\
\mathrm{X}_{1}\left(\mathrm{x}_{1}\right)\end{array}$ & $\mathrm{X}_{2}\left(\mathrm{x}_{2}\right)$ & $\begin{array}{c}\text { Response } \\
\text { functions } \\
\beta \text {-GLUC }\end{array}$ & M-GLUC & AGEN \\
\hline 1 & $10(-1)$ & $180(-1)$ & 84.42 & 37.26 & 5.72 \\
\hline 2 & $10(-1)$ & $240(1)$ & 0.00 & 0.00 & 14.37 \\
\hline 3 & $20(1)$ & $180(-1)$ & 42.83 & 29.55 & 10.00 \\
\hline 4 & $20(1)$ & $240(1)$ & 0.00 & 0.00 & 0.00 \\
\hline 5 & $10(-1)$ & $210(0)$ & 51.07 & 42.07 & 13.62 \\
\hline 6 & $20(1)$ & $210(0)$ & 0.00 & 0.00 & 13.69 \\
\hline 7 & $15(0)$ & $180(-1)$ & 65.36 & 29.40 & 10.71 \\
\hline 8 & $15(0)$ & $240(1)$ & 0.00 & 0.00 & 13.88 \\
\hline 9 & $15(0)$ & $210(0)$ & 8.09 & 53.94 & 16.74 \\
\hline 10 & $15(0)$ & $210(0)$ & 29.12 & 40.29 & 12.98 \\
\hline 11 & $15(0)$ & $210(0)$ & 2.07 & 38.58 & 14.94 \\
\hline
\end{tabular}

$\mathrm{X}_{1}$ and $\mathrm{x}_{2}$ are the coded levels of the $\mathrm{X}_{1}($ time, $\mathrm{min})$ and $\mathrm{X}_{2}$ (temperature, ${ }^{\circ} \mathrm{C}$ ) independent variables. *Response functions: $\beta$-GLU ( $\beta$-glucosides), M-GLUC (malonylglucosides) and AGEN (genistein).

Source: Research data.

\subsection{Statistical analysis}

Response surface methodology was used to analyse the regions of maximum changes of isoflavones. The models were obtained by analysis of variance (ANOVA, $p=0.05$ ) and regression analysis using Statistic 8.0 software (StatSoft Inc., Tulsa, OK, USA); graphics for the response surface and predictions were constructed. The models for each response function were expressed as the equation $Y=\beta_{0}+\beta_{1} x_{1}+\beta_{2} x_{2}+$ $\beta_{11} x_{12}+\beta_{22} x_{22}+\beta_{12} x_{1} x_{2}+\varepsilon$, where $Y$ is the response function, $\mathrm{x}_{1}$ and $\mathrm{x}_{2}$ are the levels of the coded variables, $\beta$ represents the coefficients estimated by regression and $\varepsilon$ is the error.

\subsection{Determination of contents of isoflavones by UHPLC}

The roasted soybean flour samples were defatted with hexane $(1: 10 ; \mathrm{w}: \mathrm{v})$ at $25{ }^{\circ} \mathrm{C}$ for $1 \mathrm{~h}$ by continuous rotary agitation (150 rpm), and the isoflavones extraction was performed with $300 \mathrm{mg}$ of sample and $6.0 \mathrm{~mL}$ of an extraction solution containing ultra-pure water, acetone and ethanol (at a 1:1:1, ratio) according Yoshiara et al. (2012). The mixture was then placed in an ultrasonic bath at $25^{\circ} \mathrm{C}$ for $15 \mathrm{~min}$, centrifuged at $794 \mathrm{~g}$ at $4{ }^{\circ} \mathrm{C}$ for $15 \mathrm{~min}$ (Eppendorf $5804 \mathrm{R}$, Hamburg, GE) and filtered (Millex $-\mathrm{LH}-0.20 \mu \mathrm{m})$. The separation and quantification of isoflavones were realized using Ultra High Performance Liquid Chromatography (UHPLC) as described by Handa et al. (2014). The identification of each isoflavone chemical form was performed by comparison with the absorption spectra and retention times of the respective individual patterns. The $\beta$-GLU ( $\beta$-glucosides), MGLU (malonylglucosides), and AGEN (genistein) contents were expressed in $\mathrm{mg}$ of isoflavones per $100 \mathrm{~g}$ of sample on a dry basis. 


\subsection{Results and Discussion}

According to the regression and analysis of variance (ANOVA) (Table 2) parameter for $\beta$-GLU, $x_{1}$ and $x_{2}$ showed significant negative and linear effects $(p>0.05)$. The lack of fit was not significant $(\mathrm{p}>0.05)$ and $90 \%\left(\mathrm{R}^{2}\right)$ of the experimental data were explained by the model as follows: $\beta$-GLU $=15.90-15.44 x_{1}-32.10 x_{2}$. Thus, higher content of $\beta$-glucoside isoflavones was observed when the heat treatment of the soybeans was smaller, when $\mathrm{x} 1=-1$ or 10 min and $\mathrm{x} 2$ $=-1$ or $180^{\circ} \mathrm{C}$.

Table 2 - An analysis of variance (ANOVA) for the models obtained by applying response surface methodology to the experimental data.

\begin{tabular}{|c|c|c|c|c|}
\hline Variation Source & Degrees of Freedom & $\begin{array}{c}\text {-GLU } \\
\text { SS } \quad \text { F-value }\end{array}$ & $\begin{array}{c}\text { M-GLUC } \\
\text { SS F-value }\end{array}$ & \begin{tabular}{c}
\multicolumn{2}{c}{ AGEN } \\
SS F-value
\end{tabular} \\
\hline $\mathrm{x}_{1}$ & 1 & $1431.05 \quad 7.10$ & $412.93 \quad 5.83$ & $16.69 \quad 4.72$ \\
\hline $\begin{array}{l}\mathrm{x}_{1}^{2} \\
\mathrm{x}_{2}\end{array}$ & $\begin{array}{l}1 \\
1\end{array}$ & $\begin{array}{cc}74.85 & 0.37 \\
6182.65 & 30.66\end{array}$ & $\begin{array}{cc}250.96 & 3.54 \\
1542.69 & 21.76\end{array}$ & $\begin{array}{cc}24.24 & 6.86 \\
0.54 & 0.15\end{array}$ \\
\hline $\mathrm{x}_{2}^{2}$ & 1 & $\begin{array}{ll}400.92 & 1.99 \\
\end{array}$ & 6729.48 & $50.25 \quad 14.21$ \\
\hline $\mathrm{X}_{1} \mathrm{X}_{2}$ & 1 & $432.455 \quad 2.15$ & $14.86 \quad 0.21$ & $86.97 \quad 24.60$ \\
\hline Error & 5 & 403.25 & 141.76 & 7.07 \\
\hline $\begin{array}{c}\text { Total } \\
\text { valor-P }\end{array}$ & 10 & $\begin{array}{l}9479.53 \\
p<0.05\end{array}$ & $\mathrm{p}<0.05$ & $\mathrm{p}<0.05$ \\
\hline
\end{tabular}

$\mathrm{x}_{1}$ and $\mathrm{x}_{2}$ are the coded levels of the X1(time in min) and $\mathrm{X} 2$ (temperature in $\left.{ }^{\circ} \mathrm{C}\right)$ independent variables. $\mathrm{SS}=$ sum square. ${ }^{*}$ Significant $(\mathrm{p}<0.05)$.

Source: Research data.

The higher content of $\beta$-glucosides isoflavones occur with shorter $\mathrm{x}_{1}$ and $\mathrm{x}_{2}$ during kinako processing. Assay 1 (Table $1)$, short time $(10 \mathrm{~min})$ and temperature $\left(180{ }^{\circ} \mathrm{C}\right)$, showed higher $\beta$-glucosides content with $84.42 \mathrm{mg}$ isoflavones. $100 \mathrm{~g}^{-1}$. In $\beta$-GLU (Figure 1a) had a region of maximum content for $\beta$-glucosides isoflavones forms confirming the results.

Figure 1 - Response surfaces as a function of time and temperature in kinako processing: (a) $\beta$-GLU ( $\beta$-glucosides); (b) M-GLU (malonylglucosides) and (c) AGEN (genistein).

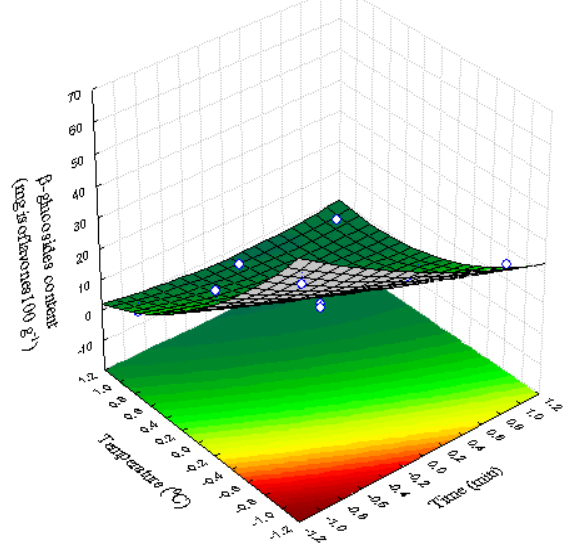

(a)

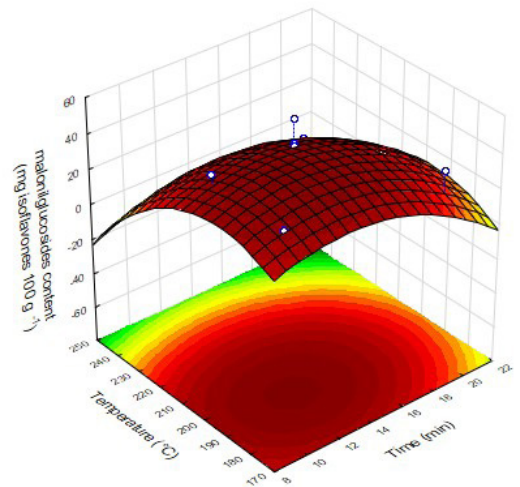

(b)

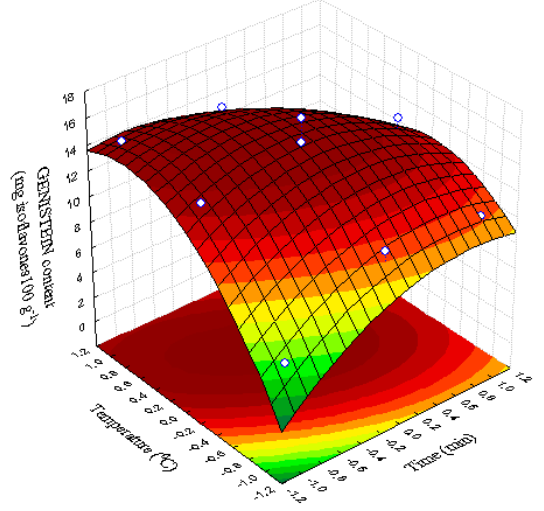

(c)

Source: Research data.

Malonylglucosides are the isoflavones forms present in larger amounts in the soybean grains (CHEN et al., 2019). During the dry heat treatment, the reduction in the levels of malonylglucosides can be attributed to the cleavage of its ester groups to form acetil and aglycones (HANDA et al., 2014).). According to the regression analysis and variance (ANOVA) (Table 2), the MGLU showed significant linear and negative terms for the $\mathrm{x}_{2}$ variable (temperature) and $\mathrm{x}_{1}, \mathrm{x}_{1}^{2}, \mathrm{x}_{2}^{2}$, and the interactions $\mathrm{x}_{1} \mathrm{x}_{2}$ was not significant $(\mathrm{p}<0.05)$. Considering the significant variable, the equation model can be described as following:

MGLU $=38.96-16.03 \mathrm{x}_{2}$.

The higher malonylglucosides content (53.94 mg isoflavones. $100 \mathrm{~g}^{-1}$ ) was obtained in the assay 9 (Table 1), with $15 \mathrm{~min}$ and $210^{\circ} \mathrm{C}$ of dry heat treatment. The model showed no significant lack of fit with the coefficients of determination $\left(\mathrm{R}^{2}\right)$ equal 0.76 indicating that the estimated model adequately fit the experimental data. Analysing the proposed model for MGLU and response surfaces in Figure $1 b$ showed the regions with maximum malonylglucosidase production (MGLU) 
when $\mathrm{X}_{1}$ (time) is $15 \mathrm{~min}$ and $\mathrm{X}_{2}$ (temperature) is $210^{\circ} \mathrm{C}$ confirming the experimental data (Table 1).

In this study, only the genistein aglycone isoflavone form was detected by UHPLC. Aglycones forms show higher biological activity and are more metabolically that can be absorbed faster in higher amounts than glycosides (HSIAO; HO; PAN, 2020). From the regression analysis and variance (ANOVA) (Table 2), the AGEN showed significant quadratic and negative terms for the $\mathrm{x}_{2}$ variable (temperature) and the interactions $\mathrm{x}_{1} \mathrm{x}_{2}$. The others terms was not significant at $p>0.05$. In view of this, the equation model can be described as following:

$$
A G E N=15.63-4.45 x_{2}^{2}-4.66 x_{1} x_{2}
$$

The higher genistein level (16.74 mg isoflavones.100 $\mathrm{g}^{-1}$ ) was obtained in the assay 9 (Table 1), with $15 \mathrm{~min}$ and $210^{\circ} \mathrm{C}$ of dry heat treatment. The model showed no significant lack of fit with the coefficients of determination $\left(\mathrm{R}^{2}\right)$ equal 0.88 indicating that the estimated model adequately fit the experimental data. Analysing the proposed model for AGEN and response surfaces in Figure 1c showed the regions with maximum genistein production (AGEN) when (time) was 15 min and $\mathrm{X}_{2}$ (temperature) was $210^{\circ} \mathrm{C}$ confirming the experimental data (Table 1). In the assay 4, we observed aglycone forms content equal $0 \mathrm{mg}$ isoflavones. $100 \mathrm{~g}^{-1}$. This result suggesting that temperatures greater than $200{ }^{\circ} \mathrm{C}$ can degrade this isoflavones forms.

Some studies have discussed the interconversion of isoflavones into aglycones during heat treatment but the appropriate time and temperature not have showed (LIMA et al., 2014; GRUN et al., 2001; HUNG et al., 2006;). The isoflavones $\beta$-glycosidic forms are predominant in soybeans grains, constituting $50-90 \%$ of the isoflavones. However, the aglycone forms, present in lower amounts, show the higher biological activity and major bioactive compounds associated with the promotion health. During thermal processing for production of soyfoods occur changes the level and profile of isoflavones. In this study, we observed only a presence of $\beta$-glucosides (daidzin, genistin and glicitin), malonylglucosides (malonyldaidzin, malonylgenistin and malonylglicitin), and genistein probably the time and temperature were not sufficient to form others isoflavones. According the authors Chen et al. (2019) the heat treatment significantly affected the isoflavone content and profile, particularly malony and acetyldaidzin or malonyl- and acetylgenistin. The author not detectable the acetyldaidzin or acetylgenistin levels or they were at very low concentrations in the soybean seeds; however, they were significantly increased in the soy flours. The emergence of acetyldaidzin and acetylgenistin could be from the decarboxylation of malonyldaidzin and malonylgenistin during the heating in this process, both the decrease of the malonyl form and the production of isoflavone glucosides (daidzin and genistin) through deacylation, i.e. deacetylation and demalonylation process, can be attributed to the increase of the ratios. Heating soyproducts and soymilk and toasting soy flour have been reported to cause conversion of isoflavone malonylglucosides to acetylglucosides and glucosides (COWARD et al., 1998; MURPHY et al., 2002); however, this effect, as far as we are aware of, has not previously been observed in the processing of soybean seeds to soy flour. The kinako can be used as ingredient in various non-meat and meat products to improve their physicochemical characteristics and functional properties (HOSODA et al., 2011; GENOVESE et al., 2007). The results showed in this paper that the kinako can to help the soyfood industry to obtain roasted whole soybean flour with higher aglycones content.

\section{Conclusion}

The kinako manufacturing process influences the isoflavone profile presented by the final product. The mathematical models obtained for glycosylated isoflavones and aglycone can be used for predictive purposes. Aiming at the higher concentration of aglycone isoflavones, the condition of $210^{\circ} \mathrm{C}$ for $15 \mathrm{~min}$ resulted in greater availability.

\section{Acknowledgements}

This work was partially funded by Fundação Araucária de Desenvolvimento Científico e Tecnológico do Paraná/ Conselho Nacional de Desenvolvimento Científico e Tecnológico-CNPq (PRONEX Program). LCSilva would like to thank CNPq for a graduate scholarship, and EII is a CNPq Research Fellow

\section{References}

BIRT, D. F.; HENDRICH, S.; WANG, W. Q. Dietary agents in cancer prevention: Flavonoids and isoflavonoids. Pharm. Ther, v.90, p.157-177, 2001. doi: 10.1016/S0163-7258(01)00137-1

CHEN, L.; TENG, H.; XIAO, J. A value-added cooking process to improve the quality of soybean: Protecting its isoflavones and antioxidant activity. Food Scie. Hum. Wellness, v.8, n.2, p.195201, 2019. doi: 10.1016/j.fshw.2019.05.001

COWARD, L. et al. Chemical modification of isoflavones in soyfoods during cooking and processing. Am. J. Clin. Nutr., v.68, p.1486S-1491S, 1998. doi: 10.1093/ajcn/68.6.1486S

DING, X.; ZENG, N.; ZHANG, G. Influence of transglutaminaseassisted ultrasound treatment on the structure and functional properties of soy protein isolate. J. Food Proc. Preserv., v.54, p. 2123-2131, 2019. doi: 10.1111/ijfs. 14117.

FANG, W. et al. Improve ethanol tolerance of $\beta$-glucosidase Bgl1A by semi-rational engineering for the hydrolysis of soybean isoflavone glycosides. Journal of Biotechnology, v. 227, p. 6471, 2016. doi: 10.1016/j.jbiotec.2016.04.022

GENOVESE, M.I. et al. Commercial soy protein ingredients as isoflavones sources for functional foods. Plants Foods Hum. Nutr., v.62, p.53-58, 2007. doi: 10.1007/s11130-007-0041-0

GRUN, I.U. et al. Changes in the profile of genistein, daidzein, and their conjugates during thermal processing of tofu. J. Agricul. Food Chem., v.49, p.2839-2843, 2001. doi: 10.1021/jf010028

HANDA, C.L. et al. Optimisation of soy flour fermentation parameters to produce $\beta$-glucosidase for bioconversion into aglycones. Food Chem., v.152, p.56-65, 2014. doi: 10.1016/j.foodchem.2013.11.101 
HOSODA, K.; FURUTA, T.; ISHII, K. Metabolism and disposition of isoflavone conjugated metabolites in humans after ingestion of kinako. Drug Metabol. Disp., v.39 p.1762-1767, 2011. doi: $10.1124 / \mathrm{dmd} .111 .038281$

HSIAO, Y. H.; HO, C. T.; PAN, M. H. Bioavailability and health benefits of major isoflavone aglycones and theirmetabolit. J. Functional Foods, v.74 p.1-8, 2020. doi: 10.1016/j.jff.2020.104164.

LEVIS, S. et al. Design and baseline characteristics of the Soy Phytoestrogens as Replacement Estrogen (SPARE) study: a clinical trial of the effects of soyisoflavones in menopausal women. Contemp Clin. Trials., v.31, p.293-302, 2010. doi: 10.1016/j.cct.2010.03.007.

LIMA, F. S.; IDA, E. I.. Optimisation of soybean hydrothermal treatment for the conversion of $\beta$-glucoside isoflavones to aglycones. Food Scie. Technol., v.56, p.232-239, 2014. doi: 10.1590/1678-4324-2019180478

LIU, Z.; KANJO, Y.; MIZUTANI, S. A review of phytoestrogens: Their occurrence and fate in the environment. Water Res., v.44, p.567-577, 2010. doi: 10.1016/j.watres.2009.03.025

LIU, K. Soybeans chemistry technology and utilization. Chapman and Hall, 1997. doi: 10.1007/978-1-4615-1763-4
MURPHY, P.A.; BARUA, K.; HAUCK, C.C. Solvent extraction selection in the determination of isoflavones in soy foods. $J$. Chromatog. B, v.777, p.129-138, 2002. doi:10.1016/s15700232(02)00342-2

PABICH, M.; MATERSKA, M. Biological Effect of Soy Isoflavones in the Prevention of Civilization Diseases. Nutrients, v.1, p.1660-1669, 2019. doi: https://doi.org/10.3390/nu11071660

RIMBACH, G. et al. Dietary isoflavones in the prevention of cardiovascular disease: a molecular perspective. Food Chem. Toxicol. v.46, p.1308-1319, 2008. doi: 10.1016/j.fct.2007.06.029

XU, Z.; WU, Q.; GODBER, J. S. Stabilities of Daidzin, Glycitin, Genistin, and Generation of Derivatives during Heating. $J$. Agricul.. Food Chem., v.50, p.7402-7406, 2002. doi: 10.1021/ jf025626i

YOSHIARA, L. Y. et al. Optimization of soy isoflavone extraction with different solvents using the simplex-centroidmixture design. Int. J. Food Scie. Nutr., v.9, p.978-986, 2012. doi: 10.3109/09637486.2012.690026

YUE, X.; ABDALLAH, A. M.; XU, Z. Thermal dynamic properties of isoflavones during tdry heating. Int. J. Food Scie. Technol., v.45, p.1878-1882, 2010. doi: 10.1111/j.13652621.2010.02346. 